\title{
Combined Immunodeficiency in Patients With Trichohepatoenteric Syndrome
}

OPEN ACCESS

Edited by:

Guzide Aksu,

Ege University, Turkey

Reviewed by:

Esther De Vries,

Tilburg University, Netherlands Mark Ballow,

University of South Florida,

United States

Neil Romberg,

Children's Hospital of Philadelphia,

United States

*Correspondence:

Frédéric Vély

vely@ciml.univ-mrs.fr

Specialty section:

This article was submitted to Primary Immunodeficiencies,

a section of the journal

Frontiers in Immunology

Received: 01 December 2017

Accepted: 25 April 2018

Published: 11 May 2018

Citation:

Vély F, Barlogis V, Marinier E,

Coste M-E, Dubern B, Dugelay E,

Lemale J, Martinez-Vinson C,

Peretti N, Perry A, Bourgeois $P$,

Badens C, Goulet O, Hugot J-P,

Farnarier $C$ and Fabre A (2018)

Combined Immunodeficiency

in Patients With

Trichohepatoenteric Syndrome.

Front. Immunol. 9:1036.

doi: 10.3389/fimmu.2018.01036
Frédéric Vély ${ }^{1,2 *}$, Vincent Barlogis ${ }^{3}$, Evelyne Marinier ${ }^{4}$, Marie-Edith Coste $^{5}$, Béatrice Dubern $^{6}$, Emmanuelle Dugelay ${ }^{4}$, Julie Lemale ${ }^{6}$, Christine Martinez-Vinson ${ }^{4}$, Noël Peretti ${ }^{7}$, Ariane Perry ${ }^{8}$, Patrice Bourgeois ${ }^{9,10}$, Catherine Badens ${ }^{9,10}$, Olivier Goulet ${ }^{11}$, Jean-Pierre Hugot $^{12,13,14}$, Catherine Farnarier ${ }^{2}$ and Alexandre Fabre ${ }^{5,10}$

${ }^{\prime}$ Aix Marseille Univ, CNRS, INSERM, CIML, Marseille, France, ${ }^{2}$ APHM, Hôpital de la Timone, Service d'Immunologie, Marseille-Immunopôle, Marseille, France, ${ }^{3}$ APHM, Hôpital de la Timone, Service d'Hématologie et Oncologie Pédiatrique, Marseille, France, ${ }^{4}$ APHP Robert Debré, Department of Pediatric Gastroenterology, Hepatology and Nutrition, Paris, France, ${ }^{5}$ APHM, Hôpital de la Timone Enfant, Service de Pédiatrie Multidisciplinaire, Marseille, France, ${ }^{6}$ Nutrition et Gastroentérologie Pédiatriques, Hôpital Armand-Trousseau, UMR-S U1166 Nutriomics, UPMC, Sorbonne University, Paris, France, 7 Department of Pediatric Nutrition, University Pediatric Hospital of Lyon, Hospices Civils de Lyon HCL, INSERM U1060, CarMeN Laboratory, University Claude Bernard Univ Lyon-1, Lyon, France, ${ }^{8}$ APHP, Hôpitaux Universitaires Paris Sud, Hôpital Antoine Béclère, Centre de référence des maladies héréditaires du métabolisme hépatique, Clamart, France, ${ }^{9}$ APHM, Hôpital de la Timone Enfant, Service de biologie moléculaire, Marseille, France, ${ }^{10}$ Aix Marseille Univ, INSERM, MMG, Marseille, France, " APHP, Necker-Enfants Malades Hospital, Department of Pediatric Gastroenterology, Hepatology and Nutrition, Paris-Descartes University, Intestinal Failure Rehabilitation Center, National Reference Centre for Rare Digestive Diseases, Paris, France, ${ }^{12}$ APHP, Hôpital Robert Debré, Paris, France, ${ }^{13}$ UMR 1149, Institut National de la Santé et de la Recherche Médicale, Paris, France, ${ }^{14}$ Labex Inflamex, Université Paris-Diderot Sorbonne Paris-Cité, Paris, France

The syndromic diarrhea/trichohepatoenteric syndrome (SD/THE) is a rare and multisystem genetic disorder caused by mutation in SKIV2L or in TTC37, two genes encoding subunits of the putative human SKI complex involved in RNA degradation. The main features are intractable diarrhea of infancy, hair abnormalities, facial dysmorphism, and intrauterine growth restriction. Immunologically this syndrome is associated with a hypogammaglobulinemia leading to an immunoglobulin supplementation. Our immune evaluation of a large French cohort of SD/THE patient revealed several immunological defects. First, switched memory B lymphocytes count is very low. Second, IFN- $\gamma$ production by $T$ and NK cells is impaired and associated with a reduced degranulation of NK cells. Third, T cell proliferation was abnormal in 3/6 TTC37-mutated patients. These three patients present with severe EBV infection and a transient hemophagocytosis which may be related to these immunological defects. Moreover, an immunological screening of patients with clinical features of SD/THE could facilitate both diagnosis and therapeutic management of these patients.

Keywords: SKIV2L, TTC37, syndromic diarrhea/trichohepatoenteric syndrome, immunodeficiency, memory $B$ cells, NK cells, T cells

\section{INTRODUCTION}

Syndromic diarrhea/trichohepatoenteric syndrome (SD/THE) was initially described by Girault et al. in 1994 (1). It is a severe and rare disorder that is characterized by intractable diarrhea, facial and hair abnormalities, intrauterine growth retardation, skin abnormalities, liver disease, and less frequently congenital cardiac defects and platelet anomaly (2). A molecular basis of SD/THE has 
been reported recently. THE syndrome 1 (OMIM, \#222470; *614589) and THE syndrome $2\left(\# 614602 ;{ }^{*} 600478\right)$ are caused by mutations in the genes encoding the tetratricopeptide repeat domain-containing protein 37 (TTC37) and superkiller viralicidic activity 2 (SKIV2L) genes, respectively. TTC37 and SKIV2L are both components of the superkiller (SKI) complex (3). The superkiller complex is a cofactor of the cytosolic exosome, which is involved in the degradation of aberrant mRNA molecules (4). The mechanism by which a defect in the mRNA degradation system leads to the symptoms associated with SD/THE remains unclear. Since its initial description, immunological defects such as low serum concentration of immunoglobulins and decreased or absent antibody responses to vaccination have been reported $(2,5,6)$.

The clinical evolution of a large French cohort of SD/THE patients has been previously described (7). Although most of these patients were administered antibody replacement therapy, $20 \%$ still died from infection, one from measles. For this reason, we investigated more deeply the B, T, and NK cell compartments to better understand the immunological defects of THES1 and THES2 patients.

\section{RESULTS}

\section{Patients Presentation}

We collected immunological data of nine patients with SD/THE syndrome caused by mutations of either TTC37 or SKIV2L which is a large cohort regarding this rare deficiency. This immunological study was performed in the Immunology Department of the Timone Hospital during patients' follow-up in four French Hospitals. All patients presented with a classical SD/THE phenotype: intractable diarrhea of infancy beginning at a median age of 31 day (0-335), need for a parenteral nutrition, hair abnormalities, and trichorhexis nodosa (8/9). Intrauterine growth restriction or small size for gestational age was noted for $7 / 9$ patients with a median birth weight of $1,580 \mathrm{~g}(1,000-2,950)$. Skin abnormalities were noted for $7 / 8$ patients and facial dysmorphy for $6 / 8$ patients. Finally, about half of the patients had hepatic abnormalities (5/8). Three patients harbored homozygous or compound heterozygous mutation in SKIV2L versus six patients with homozygous or compound heterozygous mutation in TTC37. All these variants were previously reported $(2,3)$. These patients presented a good nutritional status at the time of the sample, but only patients four and five were weaned of parenteral nutrition. The details of the clinical presentation of the patients are shown in the Table 1.

A written informed consent was obtained from each participant for the publication. This study was performed according to French ethics policy (Art. L. 1243-1 et Art. L. 1245-2 du Code de la Santé Publique).

\section{Drastic Reduction of the Circulating Switched Memory B Cells}

First, 3/6 THES1 patients and 2/3 THES2 patients displayed serum IgG values below age-appropriate normal ranges (Figure 1B). Our results showed that this humoral defect was not systematically associated with a B cell lymphopenia. CD19+
B cell counts were mostly at the lower limit of the normal ranges (Figure 1A, left panel) (8). Only 2/6 THES1 patients and $1 / 3$ THES2 patient present with low B cell count at the time of diagnosis. A reduced number of $\mathrm{CD} 27^{+}$memory $\mathrm{B}$ cells was found in all but two patients (Figure 1A, middle panel). Moreover, it appears that the number of switched memory $\mathrm{IgM}^{-} \mathrm{CD} 27^{+} \mathrm{B}$ cells was deeply reduced in all patients except for one THES1 patient who had a slight decline (Figure 1A, right panel). Interestingly, this B cell subset was reduced for the last 8 years in one patient for whom a longitudinal monitoring was performed (Figure 1C).

\section{Specific Antibody Production Is Highly Variable After Vaccination}

The evaluation of specific responses after vaccination was made difficult by the implementation of an early immunoglobulin replacement therapy. This information was not available for patients 1, 2, 5, 8, and 9. For patient 3, anti-diphtheria and anti-poliovirus responses were negative, whereas anti-tetanus antibodies were found protective 62 months after the last of seven immunization shots. Detections of anti-tetanus and antidiphtheria antibodies were positive, whereas anti-polio antibodies were negative in patient 4 at the age of 18 months. Three years after the last of four shots in patient 6 , anti-diphtheria and anti-tetanus antibodies were negative, whereas anti-measles, antimumps, and anti-rubella antibodies were positive. For patient 7 , anti-diphtheria response was positive 1 month after the fifth injection. By contrast, B cells in this patient failed to produce specific antibodies directed against tetanus, polio, haemophilus, measles, rubella, and mumps antigens after vaccination.

\section{T Cells Can Proliferate but Produce a Small Amount of IFN- $\gamma$}

As for B cells, T cell counts in patients were mostly at the lower limit of the normal ranges (Figure 1D, upper left panel) (8). There was no major difference in $\mathrm{CD} 4^{+}$and $\mathrm{CD} 8^{+} \mathrm{T}$ cell distribution (Figure 1D). The distribution between $\mathrm{CD}_{4} 5 \mathrm{RO}^{+}$memory and $\mathrm{CD}_{45 \mathrm{RA}^{+}}$naive $\mathrm{CD}^{+} \mathrm{T}$ cells was preserved (data not shown). $\mathrm{T}$-cell proliferation was monitored by quantifying CFSE-dilution within peripheral blood mononuclear cell (PBMC) after activation with either mitogens such as phytohemagglutinin (PHA), anti-CD3 antibodies, or antigens (tetanus toxoid, tuberculin, and candidin). Both antigen- and mitogen-induced proliferations were detectable but variable depending on the patient: from a normal range to vastly reduced (Table 2). PHA-induced T cell proliferation was normal in all THES2 patients and in two out of five THES1 patients. With regard to cytokine secretion, pharmacological activation of $\mathrm{T}$ cells showed a reduced number of IFN $-\gamma$ producing $\mathrm{T}$ cells in patients compared to healthy individuals (Figure 1D, bottom right panel).

\section{Hyporesponsiveness of NK Cells in Response to Target Cell or Pharmacological Activation}

$\mathrm{CD}^{-}{ }^{-} \mathrm{CD} 56^{+} \mathrm{NK}$ cell counts in SD/THE patients were low but still within normal values (Figure 2A). In the linear differentiation 
TABLE 1 | Patients characteristics.

\begin{tabular}{|c|c|c|c|c|c|c|c|c|c|}
\hline & Patient 1 & Patient 2 & Patient 3 & Patient 4 & Patient 5 & Patient 6 & Patient 7 & Patient 8 & Patient 9 \\
\hline Mutated gene & SKIV2L & SKIV2L & SKIV2L & ТТС37 & ТТС37 & ТТС37 & ТТС3 & ТТС37 & ТТС37 \\
\hline Mutation 1 & $\begin{array}{l}\text { c. } 848 \mathrm{G}>\mathrm{A} \\
\text { p. Trp283* }\end{array}$ & $\begin{array}{l}\text { c.3561_3581del } \\
\text { p.Ser1189_ } \\
\text { Leu1195del }\end{array}$ & $\begin{array}{l}\text { c. } 1635 \_1636 \text { insA } \\
\text { p.Gly546Arg fs*35 }\end{array}$ & $\begin{array}{l}\text { c.287_291del } \\
\text { p.Leu96Trp } \\
\mathrm{fs}^{*} 11\end{array}$ & $\begin{array}{c}\text { c.287_291del } \\
\text { p.Leu96Trp } \\
\mathrm{fs}^{*} 11\end{array}$ & $\begin{array}{c}\text { c. } 1708 \\
\text { C>T p.Arg570* }\end{array}$ & $\begin{array}{c}\text { c. } 2515+1 \text { G>C } \\
\text { p.Cys } 813 \text { Val } \\
\text { fs }^{\star} 56\end{array}$ & c. $3015-1 \mathrm{G}>\mathrm{A}$ & $\begin{array}{l}\text { c.3808 C>G } \\
\text { p.Pro1270Ala }\end{array}$ \\
\hline Mutation 2 & $\begin{array}{l}\text { c.1022 T>G } \\
\text { p.Val341Gly }\end{array}$ & $\begin{array}{l}\text { c.3561_3581del } \\
\text { p.Ser1189_ } \\
\text { Leu1195del }\end{array}$ & $\begin{array}{l}\text { c. } 1635 \_1636 \text { insA } \\
\text { p.Gly546Arg fs*35 }\end{array}$ & $\begin{array}{l}\text { c.287_291del } \\
\text { p.Leu96Trp } \\
\text { fs }^{*} 11\end{array}$ & $\begin{array}{l}\text { c.287_291del } \\
\text { p.Leu96Trp } \\
\text { fs*11 }\end{array}$ & $\begin{array}{l}\text { c.3185_3201dup } \\
\text { p.Lys1068Ser fs*2 }\end{array}$ & $\begin{array}{c}\text { c. } 2515+1 \mathrm{G}>\mathrm{C} \\
\text { p.Cys } 813 \mathrm{Val} \\
\mathrm{fs}^{\star} 56\end{array}$ & $\begin{array}{l}\text { c. } 4454 \text { T>G } \\
\text { p.Leu1485Arg }\end{array}$ & $\begin{array}{l}\text { c.3808 C>G } \\
\text { p.Pro1270Ala }\end{array}$ \\
\hline Intractable diarrhea & Y & Y & Y & Y & Y & Y & Y & Y & Y \\
\hline Onset of diarrhea & D31 & D21 & 0 & D21 & D335 & D72 & D204 & D31 & D19 \\
\hline Small for gestationnal age & Y & Y & Y & N & N & Y & Y & Y & Y \\
\hline Hair abnormalities ${ }^{a}$ & Y & Y & Y & Y & Y & Y & Y & Y & Y \\
\hline Facial dysmorphya & $\mathrm{N}$ & $u$ & Y & Y & $\mathrm{N}$ & Y & Y & Y & Y \\
\hline Liver disease & Y & U & N & N & $\mathrm{N}$ & Y & Y & Y & Y \\
\hline Dermatological abnormalities & Y & $u$ & Y & Y & $\mathrm{N}$ & Y & Y & Y & Y \\
\hline Cardiac abnormalities & $\mathrm{N}$ & $\mathrm{N}$ & N & N & N & $\mathrm{N}$ & N & $\mathrm{N}$ & $\mathrm{N}$ \\
\hline Hemophagocytosis & $\mathrm{N}$ & N & N & Y (EBV) & Y (EBV) & Y (Kawasaki disease) & $Y(E B V)$ & $\mathrm{N}$ & $\mathrm{N}$ \\
\hline Immunoglobulin replacement therapy (period) & $\mathrm{N}$ & Y (D99-328) & Y (D33-4,023) & $\mathrm{N}$ & $Y(D 336-1,858)$ & N & $\begin{array}{l}Y(1,009-\text { on } \\
\text { going) }\end{array}$ & $\begin{array}{l}\text { Y (D202-on } \\
\text { going) }\end{array}$ & $\begin{array}{l}\text { Y (D97-on } \\
\text { going) }\end{array}$ \\
\hline $\begin{array}{l}\text { Ig classes and subclasses and age at the } \\
\text { diagnosis }\end{array}$ & D253 & D99 & D181 & D45 & & D153 & D395 & D153 & D60 \\
\hline IgA level (g/l) & 0.56 & 0.19 & 0.07 & $<0.27$ & & 1.80 & 0.32 & 0.13 & $<0.04$ \\
\hline IgG level (g/l) & 4.10 & 1.31 & 1.85 & 3.46 & & 10.25 & 4.90 & 1.36 & 0.44 \\
\hline lgM level (g/l) & 0.50 & 0.20 & 0.30 & 0.61 & & 0.50 & 0.57 & 1.5 & 0.05 \\
\hline lgG1 level (g/l) & 2.99 & $<0.79$ & & & & & 4.68 & 3.1 & \\
\hline lgG2 level (g/l) & 0.48 & $<0.19$ & & & & & 0.59 & 0.86 & \\
\hline lgG2 level (g/l) & 0.87 & 0.126 & & & & & 0.82 & 1.16 & \\
\hline lgG4 level (g/l) & 0.05 & 0.02 & & & & & $<0.01$ & 0.04 & \\
\hline Virus infection & & & $\begin{array}{l}\text { EBV primoinfection } \\
\text { requiring Mabthera, } \\
\text { persistent EBV } \\
\text { replication }\end{array}$ & EBV & EBV & $\begin{array}{l}\text { Adenovirus infection } \\
\text { requiring hospital } \\
\text { admission in the PICU }\end{array}$ & EBV & & \\
\hline
\end{tabular}

Y, yes; N, no; U, unknown; PICU, pediatric intensive care unit.

aFacial and hair abnormalities are nearly constant feature of THE syndrome. Most of the time, hair is described as woolly, uncombable, easily removable, and poorly pigmented, and the trichohexis nodosa is found when it is sought. Facial dysmorphia is less noticeable, and it may become more evident over time. The main feature is coarse facial expressions with huge forehead and broad nasal root. 


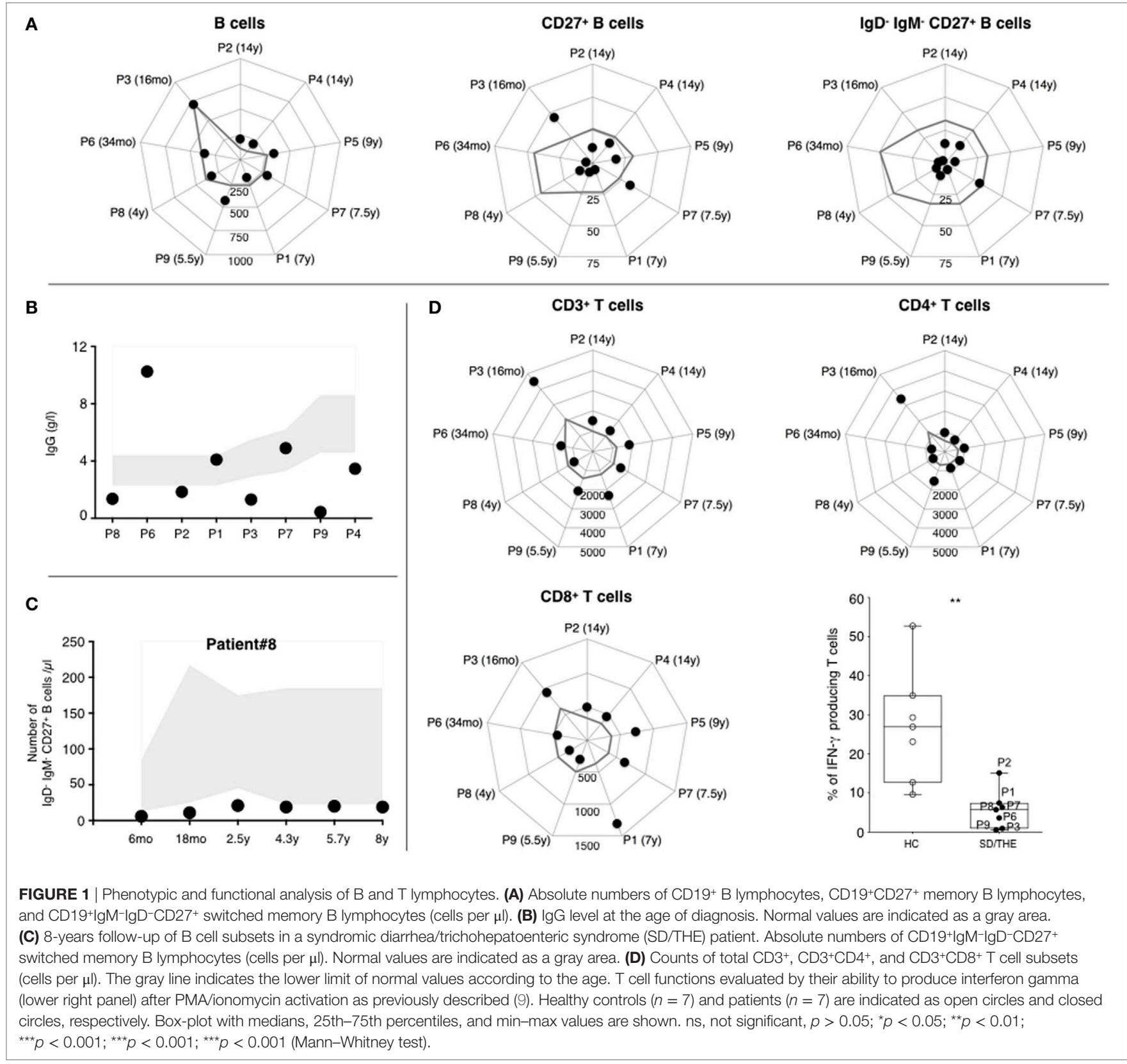

model for human NK cells, CD56 $6^{\text {bright }}$ and CD56 ${ }^{\text {dim }}$ NK cells corresponded to sequential steps in NK cell differentiation (10). CD56 ${ }^{\text {dim }}$ NK cells had high surface density of the low-affinity Fc receptor CD16 (CD16 ${ }^{\mathrm{hi}}$ ) which accounted for $90 \%$ of peripheral blood NK cells. CD56 ${ }^{\text {bright }} \mathrm{NK}$ cells (which are CD16 $6^{\text {loneg }}$ ) accounted for less than $10 \%$ of circulating NK cells. CD56 $6^{\text {bright }}$ NK cells proliferated and produced IFN- $\gamma$ in response to stimulation with cytokines, such as IL-12 and IL-18, whereas CD56 ${ }^{\text {dim }}$ NK cells were cytolytic and produced cytokines when they encountered target cells.

The CD56 bright $\mathrm{NK}$ cell subset was over-represented in our patients due to a reduced number of the CD56 ${ }^{\mathrm{dim}}$ subset
(Figure 2B). This led to higher frequency of $\mathrm{NKG}_{2} \mathrm{~A}^{+}, \mathrm{CD} 94^{+}$ NK cells, as well as a higher expression of activating NKp30 and NKp46 receptors in these patients compared to healthy individuals (Figure 2B). NK cells are innate lymphocytes involved in control of viral infection and tumor development. Thus, we further analyzed both the degranulation, which is the first step of the cytotoxic process and the IFN- $\gamma$ production. We studied the functionality of blood NK cells by PBMCs culture with medium or K562 cells for the evaluation of natural cytotoxicity, and with P815 cells coated with anti-P815 antibodies for the evaluation of the antibody-dependent cellular cytotoxicity (ADCC). NK cell degranulation, represented 
TABLE 2 | Evaluation of T cell proliferations after stimulation with mitogens and antigens.

\begin{tabular}{|c|c|c|c|c|c|c|c|c|c|}
\hline & P1 & P2 & P3 & P4 & P5 & P6 & P7 & P8 & P9 \\
\hline \multicolumn{10}{|l|}{ Mitogens } \\
\hline $\mathrm{PHA}$ & Normal & Normal & Normal & Reduced & Reduced & Reduced & nd & Normal & Normal \\
\hline Anti-CD3 & Normal & Normal & Reduced & Very low & Reduced & Very low & nd & Normal & Normal \\
\hline \multicolumn{10}{|l|}{ Antigens } \\
\hline Tetanus toxoid & Positive & nd & Positive & nd & Positive & Negative & nd & Positive & Positive \\
\hline Tuberculin & Positive & nd & Negative & nd & Positive & Negative & nd & Positive & Negative \\
\hline Candidin & Positive & nd & Negative & nd & Positive & nd & nd & Negative & nd \\
\hline
\end{tabular}

Proliferation after PHA stimulation: normal, above 55\%; reduced, between 20 and 55\%; very low, between 8 and $20 \%$. Proliferation after CD3 stimulation: normal, above 40\%; reduced, between 10 and 40\%; very low, between 2 and $10 \%$. nd, not done; PHA, phytohemagg/utinin.

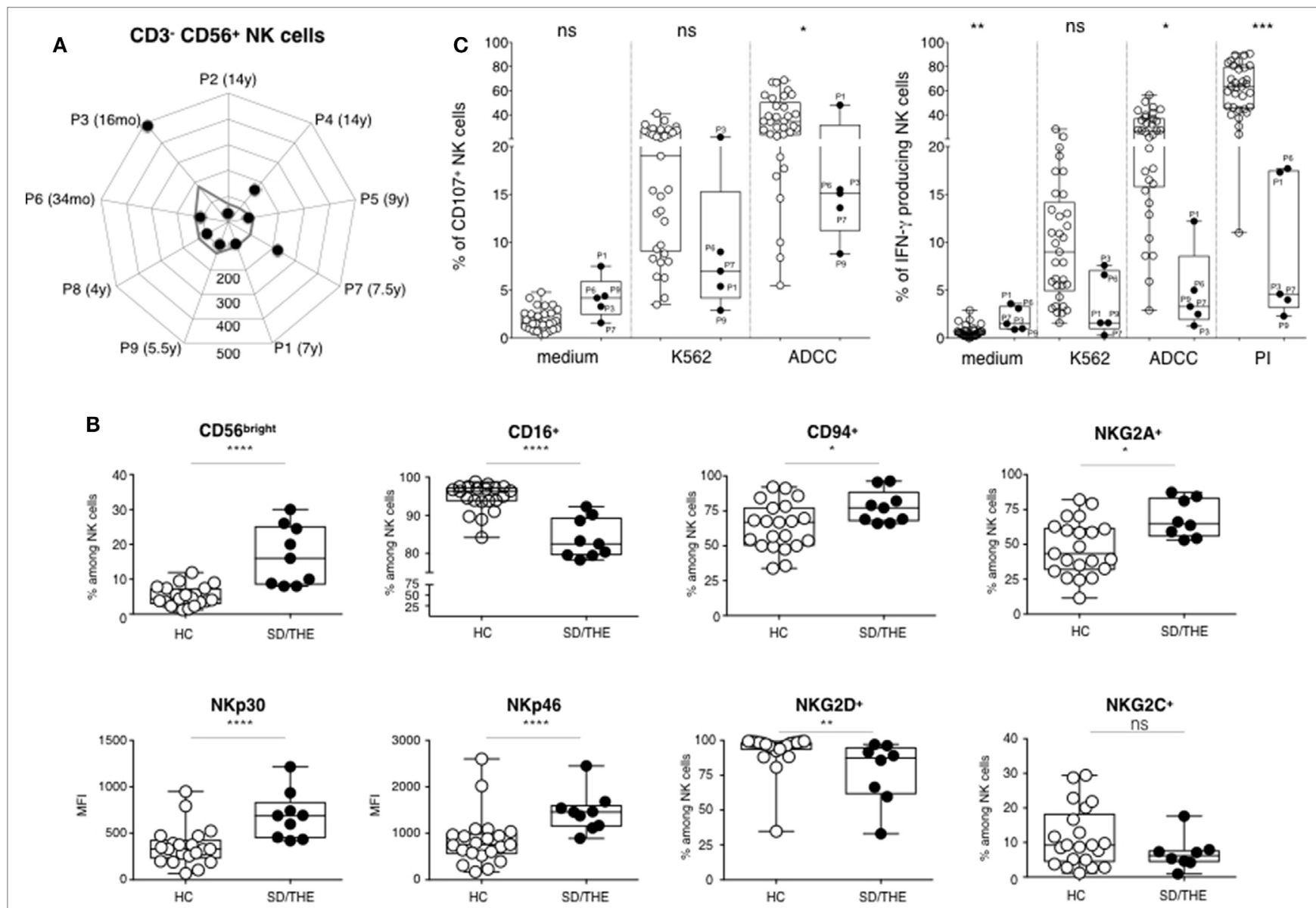

FIGURE 2 | Phenotypic and functional analysis of NK cells. (A) Absolute numbers of CD3-CD56+ NK cells (cells per $\mu$ l). (B) Cell surface expression of the indicated molecules on NK cells among the peripheral blood lymphocytes from healthy controls $\mathrm{HC}$ (closed circles) and syndromic diarrhea/trichohepatoenteric syndrome (SD/THE) patients (open circles), given as a percentage of total NK cells or as median fluorescence intensity (MFI). (C) NK cell functions evaluated by their ability to release granules and to express CD107 at the cell surface (left panel) and to produce interferon gamma (right panel) after target cell contact or PMA/ionomycin (PI) activation as previously described (9). Healthy controls $(n=33)$ and patients $(n=5)$ are indicated as open circles and closed circles, respectively. Box-plot with medians, 25th-75th percentiles, and min-max values are shown. ns, not significant, $p>0.05 ;{ }^{\star} p<0.05 ;{ }^{* *} p<0.01 ;{ }^{* \star *} p<0.001 ;{ }^{* \star *} p<0.001 ;{ }^{* \star *} p<0.001$ (Mann-Whitney test).

by the proportion of $\mathrm{CD} 107^{+} \mathrm{NK}$ cells, was reduced in $\mathrm{SD} /$ THE patients for the various conditions tested (Figure 2C, left panel). Along the same line, there is reduced number of IFN- $\gamma$ producing NK cells in patients compared to healthy controls after target cell stimulation or pharmacological activation (Figure 2C, right panel). 


\section{DISCUSSION}

Our data confirm that immunological defect is a significant feature of SD/THE patients. Lymphocyte subset analysis showed a normal or slightly reduced number of $\mathrm{CD}^{+}, \mathrm{CD}^{+}, \mathrm{CD}^{+}$, $\mathrm{CD} 19^{+}$, and $\mathrm{CD}^{-} \mathrm{CD}^{-} 6^{+}$cells. It was previously reported that $\mathrm{SD} / \mathrm{THE}$ patients could display normal memory $\mathrm{CD} 19^{+} \mathrm{CD} 27^{+}$ $B$ cell enumeration (5), which is the case for two out of nine patients in our cohort. By contrast, there was almost an absence of switched memory $\mathrm{CD} 20^{+} \mathrm{IgM}^{-} \mathrm{CD} 27^{+} \mathrm{B}$ cells in all patients and it could have been responsible for their hypogammaglobulinemia. As a matter of fact, most of them received intravenous or subcutaneous immunoglobulin replacement. That made the evaluation of specific antibody production after vaccination very difficult. Nevertheless, some patients were able to mount antigen-specific immune responses. Regarding pneumococcal immunization, all immunized patients received protein-conjugated antigens while the response to pneumococcal antigens was tested by challenging the patient with the pneumococcal capsular polysaccharides in the 23-valent pneumococcal vaccine (PPV23). This did not allow us to conclude about specific anti-pneumococcal response in our cohort. However, there are hints suggesting a problem with antibody production capacity: more than half the patients had low IgG level, specific antibody production was absent or weak after certain immunizations and B cell switched memory subset was at very low rate.

TTC37 and SKIV2L proteins are involved in RNA degradation. It was recently shown that SKIV2L is a negative regulator of RIG-I-like receptor signaling. The RNA helicase RIG-I binds to RNA of many virus. Interestingly this pathway was reported to be involved in type I IFN induction during EBV and HSV infections. Interestingly, patients with deficiencies in $\mathrm{Mcm} 4$ and Gins1, which are involved in DNA helicase complexes $(11,12)$, have a profound NK cell lymphopenia. In addition, NK cell deficiencies are frequently associated with higher susceptibility to herpes virus infections and four out nine SD/THE patients had history of EBV infection. Thus, we carried out the first phenotypic and functional evaluation of NK cells in these patients. NK cell lymphopenia was found in six patients out of nine patients due to a small number of the mature CD56 ${ }^{\mathrm{dim}}$ NK cell subset. Besides these abnormal counts, NK cells were also hyporesponsive to target cell or pharmacological activations: both degranulation and number of IFN- $\gamma$ producing NK cells were reduced in most patients. Interestingly, the number of IFN- $\gamma$ producing $\mathrm{T}$ cells was also reduced when stimulated by PMA and ionomycin.

Because of this defect and the role of TTC37 and SKIV2L proteins in RNA surveillance and degradation, these patients could be prone to infections by RNA virus. So far, only one measles death has been reported in a 18-year-old patient (7). However, over half of the nine patients have developed severe EBV infections. It remains an interesting possibility that hyporesponsiveness of NK cells combined to this T cell defect can be implicated in the occurrence of hemophagocytosis which was noted in four patients in this cohort. These transient hemophagocytosis were related to EBV infections and were not inherited forms of hemophagocytic lymphohistiocytosis in which there is an accumulation of $\mathrm{CD}^{+}$ $\mathrm{T}$ cells associated with increased secretion of IFN- $\gamma$. It is worth noting that hemophagocytosis was restricted to STHE1 patients (four out of six). Although there is no association between the intensity of the NK cell defects and the type of mutation, abnormal T cell proliferations were found only in STHE1 patients. As previously suggested, NK cell could be redundant in natural conditions if T cells and B cells are present and functional (13). Our work suggests that it is of interest to monitor T and B cell subsets as well as NK cell functions in SD/THE patients since an alteration of the adaptive immunity could emphasize the impact of this NK cell defect in the control of some viral infections, such as EBV infections.

Low class-switched B cell count has been associated with a lot of diagnosis and particularly in MAP3K14 deficiency in which a low NK cell number and function was also reported (14). Altogether, this work highlights the need for an immunological evaluation in SD/THE patients. In addition, this is the first report of phenotypic and functional NK cell defects in these patients. Finally, further studies are necessary to understand what are the molecular mechanisms by which TTC37 and SKIV2L mutations lead to such immunological disorders.

\section{METHODS}

\section{Cells and Antibodies}

Total lymphocyte, $\mathrm{CD} 4^{+} \mathrm{T}$ cell, $\mathrm{CD} 8^{+} \mathrm{T}$ cell, and $\mathrm{CD} 19^{+} \mathrm{B}$ cell populations were quantified with 6-Color BD Multitest and BD Trucount Technologies according manufacturer's instructions. NK cells were defined as $\mathrm{CD}^{-} \mathrm{CD}^{-} 6^{+}$cells within the lymphocyte size/structure gate. The following monoclonal antibodies were used: anti-CD27 (IgG1, M-T271), anti-IgD (IgG2a, IA6-2), anti-IgM (IgG1, G20-127), anti-CD56 (IgG1, B159), anti-CD3 (IgG1, SK7), anti-CD16 (IgG1, 3G8), anti-CD94 (IgG1, HP-3D9), from Becton Dickinson, San Diego, CA, USA; anti-NKp30 (IgG1, AZ20), anti-NKp46 (IgG1, 9E2), anti-NKG2A (IgG2b, Z199), and anti-NKG2D (IgG1, 1D11), from Beckman Coulter, Villepinte, France; and anti-NKG2C (IgG1, Fab 138C) from R\&D Systems, Abingdon, UK. Data acquisition and analysis were performed by using a BD FACSCanto II cytometer and FlowJo software (Becton Dickinson, Le Pont de Claix, France), respectively.

Fresh human PBMCs were isolated by Ficoll-Hypaque density gradient centrifugation (GE Healthcare), from heparintreated whole-blood samples obtained from patients or healthy volunteers.

\section{NK Cell Degranulation and IFN- $\gamma$ Production by $\mathrm{T}$ and NK Cells}

NK cell activation was monitored by assessing the ability of these cells to degranulate and to produce interferon gamma in response to several stimuli: MHC class I-negative human erythroleukemic K562 target cells, to evaluate natural cytotoxicity; mouse mastocytoma P815 cells coated with rabbit anti-mouse lymphocyte antibodies (Accurate Biochemicals, Westbury, NY, USA), to mimic ADCC and pharmacological activation with PMA and ionomycin as previously described (9). The enumeration of $\mathrm{T}$ and NK cells able to produce IFN- $\gamma$ was analyzed by intracellular staining after PMA and ionomycin stimulation. Data acquisition 
and analysis were performed by using a BD FACSCanto II cytometer.

\section{Analysis of T Cell Proliferations}

CFSE-stained PBMCs were cultured for either 3 days (mitogen activation) or 7 days (antigen activation). Proliferation was defined as the level of CFSE-dilution within T cell gate after stimulation. Mitogen concentrations were $10 \mu \mathrm{g} / \mathrm{ml}$ PHA (Oxoid), and $10 \mathrm{ng} / \mathrm{ml}$ anti-CD3 (OKT3, eBiosciences). Antigen concentrations were $5 \mu \mathrm{g} / \mathrm{ml}$ tuberculin (Statens, Denmark), $5 \mu \mathrm{g} / \mathrm{ml}$ candidin (Biorad), and 0.9 Lf/ml tetanus toxoid (Statens, Denmark). CFSEdilution was quantified by using a BD FACSCanto II cytometer.

\section{ETHICS STATEMENT}

A written informed consent was obtained from each participant for the publication of this case report. This study was performed

\section{REFERENCES}

1. Girault D, Goulet O, Le Deist F, Brousse N, Colomb V, Césarini JP, et al. Intractable infant diarrhea associated with phenotypic abnormalities and immunodeficiency. J Pediatr (1994) 125:36-42. doi:10.1016/ S0022-3476(94)70118-0

2. Fabre A, Martinez-Vinson C, Goulet O, Badens C. Syndromic diarrhea/ tricho-hepato-enteric syndrome. Orphanet J Rare Dis (2013) 8:5. doi:10.1186/ $1750-1172-8-5$

3. Fabre A, Badens C. Human Mendelian diseases related to abnormalities of the RNA exosome or its cofactors. Intractable Rare Dis Res (2014) 3:8-11. doi:10.5582/irdr.3.8

4. Schmidt C, Kowalinski E, Shanmuganathan V, Defenouillère Q, Braunger K, Heuer A, et al. The cryo-EM structure of a ribosome-Ski2-Ski3-Ski8 helicase complex. Science (2016) 354:1431-3. doi:10.1126/science.aaf7520

5. Rider NL, Boisson B, Jyonouchi S, Hanson EP, Rosenzweig SD, Cassanova J-L, et al. Novel TTC37 mutations in a patient with immunodeficiency without diarrhea: extending the phenotype of trichohepatoenteric syndrome. Front Pediatr (2015) 3:2. doi:10.3389/fped.2015.00002

6. Hiejima E, Yasumi T, Nakase H, Matsuura M, Honzawa Y, Higuchi H, et al. Tricho-hepato-enteric syndrome with novel SKIV2L gene mutations: a case report. Medicine (Baltimore) (2017) 96:e8601. doi:10.1097/ MD.0000000000008601

7. Fabre A, Breton A, Coste M-E, Colomb V, Dubern B, Lachaux A, et al. Syndromic (phenotypic) diarrhoea of infancy/tricho-hepato-enteric syndrome.ArchDisChild(2014)99:35-8.doi:10.1136/archdischild-2013-304016

8. Shearer WT, Rosenblatt HM, Gelman RS, Oyomopito R, Plaeger S, Stiehm ER, et al. Lymphocyte subsets in healthy children from birth through 18 years of age: the Pediatric AIDS Clinical Trials Group P1009 study. J Allergy Clin Immunol (2003) 112:973-80. doi:10.1016/j.jaci.2003.07.003

9. Ebbo M, Audonnet S, Grados A, Benarous L, Mahevas M, Godeau B, et al. NK cell compartment in the peripheral blood and spleen in adult patients according French rules (Art. L. 1243-1 et Art. L. 1245-2 du Code de la Santé Publique).

\section{AUTHOR CONTRIBUTIONS}

$\mathrm{FV}, \mathrm{VB}, \mathrm{CF}$, and $\mathrm{AF}$ : analysis and interpretation of data for the work; drafting the work. EM, M-EC, BD, ED, JL, CM-V, NP, AP, $\mathrm{OG}, \mathrm{J}-\mathrm{PH}, \mathrm{PB}$, and $\mathrm{CB}$ : substantial contributions to the conception or design of the work.

\section{FUNDING}

This work was supported by Institut National de la Santé et de la Recherche Médicale, Centre National de la Recherche Scientifique, Aix-Marseille Université, and by a grant from the French National Research Agency (ANR THE-RNA 2015).

with primary immune thrombocytopenia. Clin Immunol (2015) 177:18-28. doi:10.1016/j.clim.2015.11.005

10. Caligiuri MA. Human natural killer cells. Blood (2008) 112:461-9. doi:10.1182/ blood-2007-09-077438

11. Gineau L, Cognet C, Kara N, Lach FP, Dunne J, Veturi U, et al. Partial MCM4 deficiency in patients with growth retardation, adrenal insufficiency, and natural killer cell deficiency. J Clin Invest (2012) 122:821-32. doi:10.1172/ JCI61014

12. Cottineau J, Kottemann MC, Lach FP, Kang Y-H, Vély F, Deenick EK, et al. Inherited GINS1 deficiency underlies growth retardation along with neutropenia and NK cell deficiency. J Clin Invest (2017) 127:1991-2006. doi:10.1172/ JCI90727

13. Vély F, Barlogis V, Vallentin B, Neven B, Piperoglou C, Ebbo M, et al. Evidence of innate lymphoid cell redundancy in humans. Nat Immunol (2016) 17:1291-9. doi:10.1038/ni.3553

14. Willmann KL, Klaver S, Doğu F, Santos-Valente E, Garncarz W, Bilic I, et al. Biallelic loss-of-function mutation in NIK causes a primary immunodeficiency with multifaceted aberrant lymphoid immunity. Nat Commun (2014) 5:5360. doi:10.1038/ncomms6360

Conflict of Interest Statement: The authors declare that the research was conducted in the absence of any commercial or financial relationships that could be construed as a potential conflict of interest.

Copyright (c) 2018 Vély, Barlogis, Marinier, Coste, Dubern, Dugelay, Lemale, Martinez-Vinson, Peretti, Perry, Bourgeois, Badens, Goulet, Hugot, Farnarier and Fabre. This is an open-access article distributed under the terms of the Creative Commons Attribution License (CC BY). The use, distribution or reproduction in other forums is permitted, provided the original author(s) and the copyright owner are credited and that the original publication in this journal is cited, in accordance with accepted academic practice. No use, distribution or reproduction is permitted which does not comply with these terms. 